\title{
Dnaj Homolog Subfamily B Member 1
}

National Cancer Institute

\section{Source}

National Cancer Institute. Dnal Homolog Subfamily B Member 1. NCI Thesaurus. Code C122562.

Dnaj homolog subfamily B member 1 (340 aa, $238 \mathrm{kDa}$ ) is encoded by the human DNAJB1 gene. This protein plays a role in the regulation of both heat shock protein 70 activity and protein folding. 